\title{
Dinamika Syarikat Startup dalam Konteks New Normal di Yogyakarta, Indonesia
}

\section{(Dynamics Life of Startup Companies in the Context of New Normal in Yogyakarta, Indonesia)}

\author{
Azinuddin Ikram Hakim(D), Mohamad Fauzi Sukimi² \\ ${ }^{1}$ Fakulti Sains Sosial dan Kemanusiaan, Universiti Kebangsaan Malaysia (UKM), 43600, Bangi, Selangor, \\ Malaysia. \\ Email: azinuddinikram006@gmail.com \\ ${ }^{2}$ Fakulti Sains Sosial dan Kemanusiaan, Universiti Kebangsaan Malaysia (UKM), 43600, Bangi, Selangor, \\ Malaysia. \\ Email: fauzi@ukm.edu.my
}

\section{CORRESPONDING \\ AUTHOR (*): \\ Azinuddin Ikram Hakim \\ (azinuddinikram006@gmail.com) \\ KATA KUNCI: \\ Startup \\ Pandemik \\ Sosiologi pandemik \\ Normal baharu}

\section{KEYWORDS:}

Startup

Pandemic

Sociology of pandemic

New normal

\section{CITATION:}

Azinuddin Ikram Hakim \& Mohamad Fauzi Sukimi. (2022). Dinamika Syarikat Startup dalam Konteks Kenormalan baharu di

Yogyakarta, Indonesia. Malaysian Journal of Social Sciences and Humanities (MJSSH),

7(2), e001292.

https://doi.org/10.47405/mjssh.v7i2.1292

\section{ABSTRAK}

Kondisi pandemik covid-19 telah mempengaruhi pelbagai aspek kehidupan dan salah satunya adalah terhadap bidang ekonomi dan perniagaan. Syarikat-syarikat startup di Yogyakarta adalah salah satu pihak yang mendapatkan impak daripada pandemik, sehingga terdapat pola-pola pengubahan sosial dalam aktiviti mereka. Sosiologi pandemik digunakan dalam kajian ini bagi memahami fenomena perubahan sosial yang dialami syarikat-syarikat startup. Sosiologi pandemik membagikan pembahasan kepada tiga sub bahagian, iaitu, pertama berupa cabaran yang dapat dipelajari adanya pandemik, kedua fenomena pandemik yang mempersatukan antara keterkaitan manusia, alam dan teknologi, ketiga kehidupan menuju new normal. Kajian ini menggunakan reka bentuk kajian kualitatif dengan pendekatan kajian kes, selanjutnya teknik temu bual mendalam dilakukan terhadap 12 informan aktor startup. Hasil kajian menunjukkan bahawa syarikatsyarikat startup semasa pandemik ini mengalami cabaran yang besar seperti ketidakpastian pertumbuhan ekonomi. Namun di satu sisi muncul peluang baharu seperti aktiviti startup semakin banyak menggunakan teknologi maklumat dan mengurangi perjumpaan luar talian. Hal tersebut menjadi proses adaptasi startup terhadap kehidupan normal baharu. Kesimpulannya, meskipun terdapat cabaran ekonomi semasa pandemik, tetapi beberapa aktor startup tetap mencuba bertahan, berjuang, dan optimistik dapat bangkit daripada wabak pandemik.

\section{ABSTRACT}

The covid-19 pandemic condition has affected various aspects of life, included in the fields of economics and business. This study aims to provide a detailed understanding of Covid-19 pandemics' impact on startup 
entrepreneurs in Yogyakarta, Indonesia. The research used the sociology of pandemic perspective as theoretical framework to delve deeper into the shifting sociodynamics among startup entrepreneurs while navigating the pandemic. Sociology of pandemics describes three parts of the perspective; (1) mapping out the challenge that can be learned from the pandemic; (2) understanding pandemic phenomenon that unites the connection between humans, nature and technology and; (3) life towards the new normal. This qualitative study was conducted using case study as the research method. Twelve startup actors participated in this study. From the in-depth interview, the research found some interesting findings. First, startup entrepreneurs experienced complex challenges due to the pandemic. However, the pandemic has also brought new opportunities. Second, the pandemic has increased the use of digital technology for the industry's day-to-day operations and reduced the frequency of offline meetings. The second finding shows that local startup in Yogyakarta is adapting to new normal life. In conclusion, despite the economic uncertainty due to the pandemic, some startups are still trying to survive, fight, and are optimistic that they can rise in these conditions.

Sumbangan/Keaslian: Kajian ini menyumbang kepada literatur sedia ada tentang perkembangan fenomena startup di Yogyakarta, Indonesia terutama semasa pandemik Covid-19. Konsep sosiologi pandemik digunakan dalam menganalisis dinamika syarikat-syarikat startup di Yogyakarta, hal ini berkaitan dengan cabaran, peluang, strategi dan kehidupan startup dalam konteks new normal.

\section{Pengenalan}

Pada awal 2020, dunia digoncangkan dengan wabak Covid-19 yang merebak ke seluruh dunia. World Health Organization telah mengisytiharkan bahawa Covid-19 sebagai pandemik global, yang mengancam seluruh dunia. Cara penularan virus COVID-19 daripada individu kepada individu lain adalah melalui titisan daripada hidung atau mulut yang tersebar apabila seseorang dengan COVID-19 batuk atau bersin. Titisan ini merentasi objek dan permukaan di sekelilingnya. Orang lain kemudian mendapat jangkitan COVID-19 dengan menyentuh objek atau permukaan ini, kemudian menyentuh mata, hidung atau mulutnya. Tanda dan gejala jangkitan Covid-19 seperti gejala gangguan pernafasan akut seperti demam, batuk, dan sesak nafas. Tempoh jangkitan biasanya adalah selama lima hingga enam hari. Pada kes yang serius, Covid-19 dapat menyebabkan pneumonia, sindrom pernafasan akut, kegagalan buah pinggang, dan bahkan kematian (Putri, 2020).

Pandemik telah memberikan impak yang besar pada aspek kehidupan. Indonesia juga tidak terlepas daripada impak pandemik dunia yang disebabkan Covid-19 (Wahidah et al. 2020, Pramono et al., 2021). Setiap hari, terdapat peningkatan kes pesakit Covid-19 dan keadaan tersebut memerlukan perancangan dan tindakan oleh kerajaan dan kesedaran penuh masyarakat agar penyebaran virus Covid-19 dapat dibendung. Pelbagai negara melakukan lockdown untuk membendung penyebaran virus Covid-19 (Zinn, 2021). Indonesia juga telah melaksanakan lockdown atau Pembatasan Sosial 
Berskala Besar (PSBB) yang dilaksanakan di daerah-daerah tertentu (Muhyiddin, 2020). Peraturan yang berkaitan dengan penjarakan sosial dan penjarakan fizikal juga dilaksanakan sehingga mempengaruhi aktiviti sosial dan ekonomi masyarakat. Sehubungan dengan itu, adalah wajar untuk melihat dinamika syarikat-syarikat startup dalam konteks normal baharu.

\section{Sorotan Literatur}

Dalam kajian ini, konsep sosiologi pandemik yang diperkenalkan oleh Zinn (2021) digunakan sebagai alat analisis. Dalam artikelnya, Conclusions: Towards a sociology of pandemics and beyond, Zinn (2021) menjelaskan bahawa pandemik Covid-19 telah menyebabkan perubahan persekitaran awam dan cabaran ke atas amalan kebudayaan di setiap negara. Terdapat pelbagai fenomena yang dialami sistem masyarakat semasa pandemik, misalnya ada fenomena lockdown, fenomena keterkaitan antara masyarakat, alam dan teknologi, dan secara jangka panjang terdapat perubahan kebiasaan manusia, alam sekitar, dan bagaimana teknologi menjadi salah satu pembentuk kehidupan dunia masa kini.

Zinn (2021) membagi pembahasan dalam sub tiga bahagian kesimpulan kajian iaitu yang pertama berupa cabaran yang dapat dipelajari adanya pandemik, kedua iaitu fenomena pandemik yang mempersatukan antara keterkaitan manusia, alam dan teknologi, ketiga iaitu pada kehidupan menuju new normal atau kenormalan baharu. Konsep sosiologi pandemik diperkenalkan oleh Zinn (2021) berdasarkan perubahan sosial selama pandemik, termasuk kepada aktiviti ekonomi dan perniagaan. Beliau menerangkan sosiologi pandemik secara utuh berdasarkan daripada sosiologi kesihatan. Namun dalam kajian ini, konsep Zinn (2021) tentang sosiologi pandemik dibentangkan dalam analisis sosiologi ekonomi.

Menurut Kuckertz et al. (2020) pihak kerajaan berusaha mencuba melaksanakan dasar yang berubah drastik, lockdown menjadi sebuah kebijakan yang diterapkan seluruh negara dalam rangka pencegahan virus korona. Hal ini secara langsung mempengaruhi perubahan kehidupan sosial masyarakat dan kehidupan ekonomi, memberikan kejutan kepada aktor-aktor ekonomi, tak terkecuali syarikat startup inovasi. Startup merujuk kepada sebuah perniagaan yang berada pada tahap permulaan, sebuah kelompok yang sedang memulai atau lahir sebagai syarikat/badan perniagaan yang masih pada fasa awal memperjuangkan kewujudan mereka. Startup merupakan entiti yang berdiri berdasarkan idea-idea cemerlang dan cita-cita untuk mencapai kejayaan yang besar, sebagai contoh di dalamnya terdapat pengurusan organisasi dan keusahawanan (Salamzadeh \& Kesim, 2015).

Kuckertz et al. (2020) dalam artikelnya bertajuk Startup in time of crisis, A rapid response to Covid-19 Pandemic (2020) memaparkan bahawa para pelaku keusahawanan harus menghadapi konsekuensi daripada krisis ini, menghadapi cabaran baharu, dan juga mencari potensi dalam kehidupan penuh risiko. Dengan adanya pandemik, para pelaku startup berada di tahap yang rapuh dan terancam. Keadaan tersebut bertambah kritikal kerana krisis pandemik yang menyebabkan ketidakpastian ekonomi, sosial dan ekosistem perniagaan.

Di satu sisi, Kuckertz et al. (2020) menyebutnya sebagai entrepreneurial crisis, iaitu, semasa pandemik muncullah beragam krisis sama ada dari segi konsumsi masyarakat, ketidakpastian, dan menuntut pelaku startup untuk membina banyak inovasi dan 
eksperimen. Lebih lanjut menurut Kuckertz et al. (2020) terdapat krisis pengurusan dalam syarikat startup kerana adanya ketidaksediaan dalam menghadapi fenomena pandemik.

Menurut Aditif (2021), keadaan startup di Yogyakarta memperlihatkan potensi perkembangan startup atau industri digital kreatif yang baik. Salah satunya kerana disokong oleh pelbagai pihak, sama ada mendapat sokongan daripada pihak universiti, atau mendapat taraf inkubator atau mendapat sokongan daripada sejumlah persyarikatan milik kerajaan. Semasa pandemik, Aditif (2021) menjelaskan bahawa kondisi luaran pandemik Covid-19 ini menghambat pertumbuhan startup di Indonesia, hal ini tidak terlepas dari kelesuan tahap konsumsi masyarakat, adaptasi, dan pola kerja baharu dari semua sektor pelaku startup. Adanya amalan kerja atas talian telah mengharuskan pelaku startup digital beradaptasi dengan teknologi maklumat. Sehubungan dengan itu, dalam perbincangan kajian ini, pengkaji mencuba membincangkan perusahaan Startup di Yogyakarta dalam konteks cabaran, hubung kait antara manusia, alam dan teknologi, dan kehidupan kenormalan baharu seperti dalam konsep Zinn (2021).

\section{Metod Kajian}

Kajian ini menggunakan pendekatan kualitatif bagi menjawab persoalan dan memenuhi objektif kajian yang telah ditentukan. Menurut Creswell (2004) pendekatan kualitatif adalah bertujuan untuk mengumpulkan makna daripada para informan, berfokus pada satu konsep atau fenomena, membawa nilai-nilai peribadi ke dalam penyelidikan, meneliti konteks atau latar belakang informan, mengesahkan penemuan, menginterpretasikan dan menganalisis data. Dalam hal ini pengkaji berusaha membina makna tentang suatu fenomena berdasarkan pandangan-pandangan para informan di mana pengkaji juga berusaha memahami isu tersebut (Creswell 2004).

Dalam menjelaskan fenomena startup yang sedang bermunculan di Yogyakarta, pengkaji memilih jenis penyelidikan kajian kes. Menurut Creswell (2007), kajian kes termasuk dalam jenis kajian pendekatan kualitatif, yang lebih berfokus pada suatu kes khusus ataupun pada sebahagian kes-kes tertentu secara rinci dan mendalam. Dalam proses mendapatkan data primer, kaedah temu bual dan pemerhatian dilakukan ke atas aktor startup di Yogyakarta. Temu bual adalah suatu proses yang memungkinkan pengkaji berinteraksi dengan informan dan mampu menjelaskan soalan dengan lebih mudah serta mampu mendapatkan jawapan secara terus daripada informan (Hamzah, 2010). Bagi data sekunder, kajian kepustakaan dilakukan ke atas bahan bacaan seperti buku, jurnal, tesis, buku ilmiah bahan audiovisual, dokumen, dan laporan yang berkaitan dengan startup.

Pemilihan informan adalah berasaskan teknik purposive sampling, iaitu, informan ditentukan ditentukan berdasarkan ciri-ciri yang sesuai tujuan penyelidikan itu sendiri. Penyelidik menentukan ciri-ciri informan sebagai berikut, iaitu, belia pelaku startup di Kawasan Provinsi Daerah Istimewa Yogyakarta dapat berupa pengasas komuniti startup, syarikat Startup telah berumur antara 1-5 tahun, aktor startup berusia sekitar 20-35 tahun. Manakala untuk pihak luaran startup, pengkaji memilih berasaskan keahlian atau kepakaran seseorang yang memahami fenomena belia dan startup, selain itu juga individu yang memahami dasar kerajaan berkaitan startup di Daerah Istimewa Yogyakarta. 


\section{Hasil dan Perbincangan Kajian}

Semasa pandemik muncul banyak persoalan dan ditanggapi dengan pelbagai cara berbeza. Secara ringkas beberapa isu dan cabaran sosial membalas isu pandemik, sosiobudaya, secara pengalaman institusi dalam menjawab krisis global dan tingkat kebangsaan. Hasilnya terdapat beberapa isu penting yang mempengaruhi masyarakat semasa pandemik di antaranya iaitu inekualiti, stigma, kepercayaan, risiko rasional, risiko komunikasi, wacana diskursus dan dinamika risiko global. Pandemik telah memberikan ancaman yang berbeza-beza bahagi skala global dan konsekuensi yang harus dihadapi pihak kerajaan pihak kerajaan menyediakan beragam balasan di setiap persoalan yang berbeza, virus ini telah mengawal menjadi wabak baharu, diperlukan dasar untuk mengawal hal ekonomi, sosial, dan sistem kesihatan (Zinn, 2021).

Dalam sistem ekonomi misalnya telah memberikan impak kepada syarikat-syarikat startup (Kuckertz et al., 2020). Di kawasan Daerah Istimewa Yogyakarta, Indonesia misalnya terdapat muncul banyak startup baharu sebagai salah satu bentuk aktiviti perniagaan yang berasaskan inovasi dan digital teknologi (Aditif, 2021). Kemunculan pandemik ini tak lepas turut mempengaruhi perkembangan startup di Yogyakarta. Dalam penyelidikan ini, pengkaji menjelaskan cabaran dan peluang apa sahaja yang dilakukan para pengasas startup dalam menghadapi pandemik.

\subsection{Profil informan kajian}

Dalam kajian ini, sebanyak sembilan (9) orang informan yang mewakili syarikat startup telah dipilih sebagai informan dalam kajian ini. Mereka adalah terdiri daripada pengasas, ketua syarikat, pengurus bahagian teknologi, komunikasi, dan pemasaran. Syarikat startup yang dipilih adalah daripada kategori perniagaan yang berbeza merujuk kepada Jadual 1, iaitu terdapat beberapa bidang seperti bidang teknologi, kesihatan, pertanian, pendidikan, dan sebagainya. Selain informan, pengkaji juga telah menemu bual beberapa inkubator startup, pihak universiti, dan pihak kerajaan untuk mendapatkan gambaran tentang perkembangan startup di Yogyakarta. Pihak kerajaan dalam hal ini diwakilkan oleh rasmi Dinas Komunikasi dan Informatika Yogyakarta yang mengurus program kerja yang berkaitan dengan startup.

Jadual 1: Profil informan startup di Yogyakarta

\begin{tabular}{llllll}
\hline No & Nama & Umur & Jawatan & $\begin{array}{l}\text { Bidang Startup \& } \\
\text { Syarikat }\end{array}$ & $\begin{array}{l}\text { Tahun } \\
\text { Berdiri } \\
\text { Startup }\end{array}$ \\
\hline 1 & Cahaya & 26 th & Pengasas & $\begin{array}{l}\text { Tenaga boleh } \\
\text { diperbaharui }\end{array}$ & 2018 \\
2 & Mufid & 31 th & Pengasas & Kesihatan & 2019 \\
3 & Igman & 30 th & Pengasas & Pertanian & 2020 \\
4 & Martha & 35 th & Pengurus & Sosial \& Lingkungan & 2019 \\
5 & Risyad & 24 th & Pengasas & Anak & 2020 \\
6 & Nurist & 25 th & Pengasas & Pendidikan & 2020 \\
7 & Puspa & 21 th & Pengasas & Game atau permainan & 2019 \\
8 & Pirli & 30 th & Pengasas & Masakan & 2020 \\
9 & Rene & 22 th & Pengasas & Psikologi & 2020 \\
10 & Matahari & 31 th & Pengurus & Inkubator di universiti & 2017 \\
11 & Amadea & 26 th & Pengurus & Inkubator & 2018 \\
12 & En. Rony Primanto & 50 th & Ketua & Pihak Kerajaan & - \\
\hline
\end{tabular}




\subsection{Peluang dan Cabaran Startup di Masa Pandemik}

Semua bentuk perniagaan mendapatkan impak daripada kejadian pandemik. Pada awal pandemik, kondisi perniagaan di Indonesia ramai yang berguguran dan bankrap, hal ini kerana sistem perekonomian yang sempat terhenti. Kajian oleh Katadata (2021) menyatakan bahawa sebahagian besar syarikat startup mengalami masa sulit selama pandemik Covid-19. Sebelum adanya pandemik, sebanyak 74,8\% perusahaan memiliki kondisi yang baik, namun ketika datangnya pandemik menjadi hanya purata 33\% perusahaan sahaja yang dalam kondisi baik. Hal ini menunjukkan adanya penurunan dan bankrap pada beberapa sektor syarikat, seperti sektor pelancongan, jasa, penerbangan dan maritim (Katadata, 2021; Muhyiddin, 2020). Sedangkan startup dapat berjalan dengan baik, iaitu, bidang pembayaran digital, agrikultur dan kesihatan (Katadata, 2021). Aditif (2021) menyatakan bahawa terjadi hambatan atas pertumbuhan dan perkembangan startup di Yogyakarta semasa pandemik, namun di beberapa tempat inkubator justeru muncul startup-startup baharu.

Dalam kajian ini, sembilan startup yang pengkaji selidiki memiliki fasa muncul yang berbeza, tetapi ada empat startup yang muncul justeru sesudah adanya wabak pandemik. Setiap startup memiliki strategi dan cabaran berbeza dalam menghadapi pandemik global untuk sekadar bertahan dan melanjutkan keberlangsungan startup. Pandemik telah memberikan impak positif dan negatif. Banyak hal yang harus syarikatsyarikat startup sedia untuk menghadapi situasi, kondisi, dan realiti startup semasa pandemik (Kuckertz et al., 2021). Beberapa startup memiliki cabaran dan strategi yang berbeza-beza dalam menghadapi pandemik, dan tentu hal ini berkenaan dengan dasar yang mereka ambil dalam putusan syarikat.

\subsubsection{Impak Positif: munculnya startup baharu semasa pandemik}

Kondisi pandemik kerap kali dilekatkan pada krisis perniagaan, tetapi di satu sisi daripada pandemik ini dapat muncul startup baharu. Dalam kajian ini ditemukan bahawa semasa pandemik telah muncul beberapa startup baharu semasa pandemik. Nurist sebagai pengasas berpendapat bahawa pandemik memiliki sisi positif untuk perkembangan startup. Startup yang dibina Nurist ini muncul kerana adanya pandemik, iaitu startup yang bergerak di bidang pendidikan perniagaan.

"Semasa Indonesia mengalami krisis ekonomi 98, sesuatu hal yang saya baca dan pelajari adalah munculnya orang kaya baharu, semasa mula pandemik ada, banyak berita beredar sangat mencekam tetapi menurut saya justru punya peluang disana seperti tokoh-tokoh nasional yang dapat bangkit daripada krisis ekonomi kala itu". (Nurist)

Beberapa startup yang lain merasakan peningkatan pelanggan. Mufid sebagai pengasas startup di bidang kesihatan juga merasa termasuk yang mendapatkan impak positif daripada adanya pandemik. Mufid menjelaskan bahawa kerana kecocokan daripada sisi visi dan misi syarikat yang bergerak di bidang kesihatan. Mufid menjelaskan bahawa banyak kesedaran pelanggan terhadap kesihatan dan gizi.

"Adanya pandemik ini membuat masyarakat Indonesia tergerak memahami soal makanan yang dapat meningkatkan kesihatan jadi itu berimpak bagus terhadap perkembangan syarikat saya, hal ini dapat 
dilihat dari pencarian di google yang terus meningkat berkaitan dengan pertanyaan kesihatan baik di website maupun di youtube, dan bahkan lonjakan dan peningkatannya cukup bererti". (Mufid)

Perkembangan syarikat startup milik Mufid sangat cepat kerana banyak pelanggan yang terbantu dengan maklumat kesihatan seperti makanan sihat saat terjangkiti covid-19, dan pelayanan konsultasi gizi. Hal ini selaras dengan startup miliki Martha yang mendapatkan tambahan pelanggan, hal ini kerana pelanggan tergerak untuk sedar akan amalan kebersihan dan mengawal sampah, startup yang bergerak di bidang sosial. Startup milik Pirli merupakan startup di bidang masakan dalam talian atau catering online, Pirli mencontohkan dengan adanya kebijakan persekatan maka ramai orang memesan masakan dan dihantar ke rumah.

Syarikat startup lain, seperti milik Risyad termasuk salah satu startup yang berpindah arah tujuan kerana adanya pandemik, menurut Risyad berdasarkan hasil penyelidikan terhadap pelanggan, produk teknologi yang dimiliki syarikat mereka sangat potensi tetapi ketika pandemik datang maka keperluan dan keutamaan itu bergeser, akhirnya beralih daripada startup di bidang teknologi ke arah kesihatan anak. Di sisi yang lain, kesedaran terhadap digital mengalami peningkatan, hal ini disampaikan Matahari bahawa masyarakat memiliki kesedaran pentingnya digital di masa pandemik, sebagai contoh ia berjaya mengembangkan pasar tradisional menjadi pasar digital talian.

\subsubsection{Impak negatif: ketidakpastian pandemik dan syarikat}

Selain impak positif, tentu terdapat impak negatif yang menimpa syarikat-syarikat startup di Yogyakarta. Semisal ada beberapa startup yang mengalami penurunan pendanaan dan juga bankrap (Kuckertz et al., 2020; Muhyiddin, 2020). Seperti contoh, Cahaya merasa bahawa cabaran utama daripada pandemik ialah ketidakpastian akan wabak pandemik itu sendiri.

"Startup penuh dengan ketidakpastian, pandemik ini ke depan akan menurun atau apakah meningkat kesnya, daripada pandemik ini banyak sekali startup yang kalah bertarung, dan juga pendanaan dialihkan sepenuhnya untuk bencana wabak covid, tentu hal ini berpengaruh ke arah bentuk investasi, keamanan, daya konsumsi masyarakat". (Cahaya)

Selaras dengan Cahaya tentang daya konsumsi masyarakat berkurang, hal ini berpengaruh pada penjualan produk pertanian startup milik Igman. Igman menyatakan cabaran ke depan iaitu persaingan di dunia startup yang semakin sulit dan ramai. Di sisi lain, Martha mengatakan bahawa adanya pandemik membuat kumpulan kehilangan terget pelebaran layanan yang belum dapat terwujudkan. Kemudian persoalan dalam kesihatan itu sendiri, pandemik telah memberikan ancaman kepada para pekerja di bidang syarikat startup, Martha memiliki pengalaman memiliki pengurus yang sempat terjangkiti covid-19, hal ini cukup membuat kesulitan dalam menjalankan syarikat.

Menurut Amadea, impak negatif yang menimpa startup di Kawasan Yogyakarta lumayan banyak, kerana syarikat-syarikat startup yang berada di Yogyakarta itu masih berumur sangat muda, sehingga ada beberapa dari mereka yang memang tidak dapat bertahan dan pada akhirnya beberapa dari mereka mengalami kegagalan. Menurut Amadea, semisal ada beberapa startup di bidang pelancongan itu harus sangat berjuang dalam menghadapi pandemik. Pelancongan menjadi sektor yang sangat mendapatkan impak 
negatif dari awal adanya pandemik. Beberapa startup lain terdapat permasalahan pendanaan, persoalan dengan pelabur, dan beberapa bankrap kerana tidak dapat bertahan lagi (Katadata, 2020; Tiffany et al., 2021).

\subsubsection{Strategi kumpulan startup}

Strategi yang tepat diperlukan guna menghadapi cabaran dan peluang startup semasa pandemik. Strategi iaitu sebuah aktiviti penuh daya saing dengan pendekatan perniagaan agar mencapai sebuah kerjaya yang memuaskan, hal ini dengan menggunakan pelbagai cara dan situasi. Pengurusan strategi didefinisikan sebagai seni dan ilmu dalam menjalankan syarikat demi mencapai tujuan, hal ini ditetapkan oleh pemimpin dan seluruh pihak dalam syarikat. Di satu sisi, pengurusan strategi juga merupakan kemampuan dalam berfikir, mengelola organisasi, bagaimana membina sebuah perencanaan sesuai konteks perusahaan (Tiffany et al., 2020).

Dalam kajian ini ditemukan bahawa setiap startup memiliki strategi yang berbeza dalam menyikapi pandemik. Beberapa di antara strategi iaitu terdapat penguatan dalaman kumpulan startup, mencari peluang baharu daripada celah pandemik, berusaha menjalin membina kerja sama dengan pihak-pihak luaran yang dapat menyokong startup, dan meningkatkan kualiti produk.

Hal yang dilakukan Rene untuk bertahan melalui pandemik iaitu yang pertama adalah penguatan dalaman kumpulan agar lebih kompak, mengawal komunikasi berjalan dengan baik, dan saling menjaga motivasi. Strategi lain untuk mendapatkan pelanggan lebih iaitu lebih fokus pada isu yang sedang ramai diperbincangkan di Indonesia. Rene mencuba lebih fokus membina produk dan perniagaan yang baik sehingga harapannya akan menarik pihak pelabur.

Strategi yang dilakukan Pirli adalah mencuba untuk lebih banyak membuka relasi kerja sama dengan sesama pengasas syarikat startup di seluruh Indonesia. Pirli mencuba mengikuti kumpulan pengasas startup, supaya dapat saling mengenal, dalam rangka melihat peluang kerja sama yang semakin luas. Serupa dengan strategi yang dilakukan Pirli, Puspa tetap mencari pelbagai peluang pertandingan startup permainan baik di dalam negeri atau antarabangsa, mencuba menjalin relasi kerja sama dan mengikuti pelbagai perisiwa startup yang ada.

"Selama kumpulan startup memenuhi persyaratan yang ada boleh mendaftarkan diri untuk mengikutinya, startup kami akan cuba ikut". (Puspa)

Matahari menyatakan strategi inkubator dengan mencuba melakukan pendanaan kreatif agar dapat membina lebih banyak kerja sama, baik daripada sisi dalaman ataupun yang sifatnya sebagai percepatan terhadap syarikat startup yang telah lulus pelatihan di inkubator universiti. Amadea menjelaskan strategi yang dilakukan adalah lebih memaksimumkan proses menjadi global connector bahagi startup di Yogyakarta, Inkubator daripada Amadema berusaha membuka aktiviti untuk memperjumpakan kepentingan, pembinaan, syarikat, pelabur, universiti, pihak kerajaan, dan pihak-pihak terkait untuk memperkenalkan syarikat startup yang dibina.

"Hal ini agar harapannya ada kebijakan-kebijakan yang baik untuk ekosistem startup di Yogyakarta". (Amadea) 
Sedangkan cabaran daripada pihak kerajaan iaitu bagi En. Rony adalah pada peningkatan kapasiti modal manusia agar lebih maksimal, menambah relasi dan kerja sama dengan pelbagai pihak, pihak kerajaan berupaya menjadi penghubung antara startup dengan pelabur.

\subsection{Fenomena pandemik yang mempersatukan antara manusia, alam dan teknologi}

Upaya dalam mengawal dan mencegah sebaran virus korona dilakukan dengan kebijakan sekatan orang ramai dan penjarakan fizik satu dengan yang lain. Hal ini mengharuskan pelbagai startup untuk siap dalam menghadapi pelbagai kemungkinan ketika krisis pandemik (Kuckertz et al., 2020). Kebijakan itu berimpak terhadap seluruh aspek kehidupan, termasuk di antaranya proses rapat dalam talian. Beberapa syarikat wajib melaksanakan rapat dalam talian seperti menggunakan aplikasi Zoom atau Googlemeet (Karl et al., 2021), sesuatu hal yang paling terasa sebagai impak positif daripada pandemik. Rapat dalam talian ini menyebabkan berkurangnya peristiwa luar talian sebagai peristiwa yang biasa terjadi di pelbagai aktiviti startup di Yogyakarta.

Berdasarkan data yang dihimpunkan oleh Aditif (2021) yang menyelidik tentang kondisi industri kreatif digital di Yogyakarta semasa pandemik iaitu cenderung aman daripada ancaman pandemik kerana sifatnya sendiri yang sudah 'digital', maka ketika praktik dalam talian dilakukan itu tidak terlalu lama untuk harus beradaptasi dengan teknologi talian, selain itu modal manusia juga telah terlatih dengan adanya kemahiran teknologi maklumat.

"Ada impak positif dan negatifnya, positifnya kita boleh rapat tidak harus berjumpa langsung, boleh bincang dalam talian yang sebelumnya tidak terbiasa sekarang menjadi hal yang terbiasa. Bahkan untuk sekarang, untuk janjian pun boleh bila sahaja. Sehingga positifnya startup kami dapat bergerak sangat cepat, teknologi itu boleh mendekatkan yang jauh menjadi lebih dekat". (Cahaya)

Hal-hal yang paling berpengaruh bagi Cahaya adalah kemudahan akses di bidang maklumat. Pendapat Cahaya ini dilengkapi oleh pendapat para pelaku startup yang lain yang menyetujui rapat dalam talian sebagai bentuk percepatan di bidang komunikasi digital. Rene merasakan adanya percepatan dalam pengembangan startup dan semua akses menjadi terbuka lebar. Sebagai contoh semasa pandemik, pengurusan pengajuan pentadbiran terhadap syarikat dan hak paten lebih cepat dalam sistem talian. Rene menjelaskan bahawa dengan adanya sistem talian dapat bergung ke dalam inkubator yang bagus di Jakarta meskipun kumpulan startup berada di Yogyakarta. Selanjutnya, menurut Rene iaitu yang sebelumnya komunikasi antar mentor startup harus berjumpa langsung di kafe sekarang hanya perlu memerhatikan dalam talian, untuk kerjasama juga dapat dilakukan dalam talian, sehingga memberikan banyak keuntungan.

"Semua akses yang sebelumnya ada terhad di pelbagai kawasan sekarang dapat terbuka luas, sehingga startup kami dapat berdiri seperti sekarang ini, kerana adanya pandemik, akses terbuka, maka ada acara webinar online, belajar-belajar online, konsultasi psikologi boleh online juga". (Rene) 
Risyad, Puspa, dan En. Rony merasa bahawa dengan adanya pandemik itu mempercepat akselerasi sistem teknologi maklumat. Dengan adanya sistem talian itu kumpulan startup Risyad dan Puspa jadi berfikir bagaimana cara untuk bekerja lebih efektif dalam talian, maka dibuatlah sistem evaluasi kerjaya dalam talian, hal ini secara tidak langsung mempercepat perkembangan syarikat startup. Menurut Karl et al. (2021) idea untuk melaksanakan webinar sebelum pandemik adalah hal yang tidak terbayangkan, namun semasa pandemik kegiatan webinar talian dapat dilakukan dimana sahaja, dapat diakses di pelbagai tempat.

\begin{abstract}
"Tanpa adanya pandemik mungkin kita baru 10 tahun lagi dapat merasakan kondisi hari ini, tapi sekarang sudah dapat kita rasa sekarang percepatannya". (Risyad)

"Kita buka pikiran bahawa pandemik ini adalah sebuah batu loncatan dan mesin waktu, ada percepatan di mana kita bergerak lebih cepat dan jauh, dua tiga langkah lebih maju, adaptasi orang semakin cepat terhadap teknologi, mengenal bagaimana rapat dalam talian, guna pakai Zoom atau Google Meet, bagaimana mengatur perkara talian berjalan dengan baik, mengurus pentadbiran dan surat secara dalam talian". (Puspa)
\end{abstract}

Kerana adanya dasar dalam talian, maka Nurist menjelaskan dapat melakukan pelatihan perniagaan dalam talian. Sedangkan untuk koordinasi kumpulan, startup milik Mufid dan Martha sudah terbiasa melaksanakan mesyuarat dalam talian jauh sebelum pandemik ada. Martha menjelaskan bahawa untuk rapat talian kumpulan sudah sering melakukan sebelum pandemik kerana juga kondisi pengurus yang jarang berjumpa luar talian, dalam rapat talian tersebut biasanya setiap divisi melaporkan progres kerjaya masing-masing.

Zinn (2021) menyatakan bahawa dengan adanya fenomena digital teknologi ini, tentu berpengeruh kepada pengubahan iklim, misalnya dengan adanya perjumpaan maya dalam talian ini telah menekan angka penerbangan sehingga menekan pada sumber produksi gas dan minyak. Di satu sisi, dengan adanya kos penerbangan dan transportasi yang berkurang, perusahaan tentu dapat menyimpan pendanaan untuk keperluan lain, hal ini dengan mengurangi perjalanan fizikal dengan rapat dalam talian, meskipun perjumpaan bersemuka juga merupakan suatu keutamaan, tetapi adanya kebijakan work from home ini membuat perusahaan dapat bekerja lebih efektif. Di satu sisi alam mendapatkan manfaat dengan berkurangnya aktiviti penggunaan gas untuk transportasi sehingga membantu lingkungan untuk pulih dan pencemaran yang berkurang (Zinn, 2021).

\title{
4.4. Kehidupan menuju New Normal (Kenormalan baharu)
}

Semasa bermula adanya wabak pandemik, terdapat sebutan konsep kenormalan baharu terdengar merebak di pelbagai lini kehidupan. Menurut Buheji, Ahmed dan Tahrami (2020) kondisi semasa dan setelah covid-19 disebut dengan sebagai kenormalan baharu atau normal baharu. Suatu era yang penuh dengan cabaran dan ketidakstabilan, penuh dengan keingintahuan, risiko, pembelajaran dan transformasi. Konsep kenormalan baharu ini berpunca kepada konsep yang dirasakan dari pelbagai pengalaman dunia tetnang persoalan sosial dan ekonomi yang mengalami banyak pengubahan. 
Zinn (2021) mencontohkan kondisi kenormalan baharu dengan ketidakpastian virus ini akan bertahan dalam masa yang lama atau tidak, di satu sisi kondisi sebaran vaksin sudah mulai dilakukan, dan juga upaya-upaya seperti merawat bercuci tangan secara rutin, penjarakan sosial, pengesanan kontak dan juga kebijakan sekatan pergerakan. Hal ini diperlukan kesedaran bahagi setiap lapisan masyarakat, kefahaman, maklum balas dan sokongan menghadapi masa kondisi pandemik. Diperlukan aspek sosial dalam membina kebijakan dalam maklum balas fenomena ini.

Hal yang paling terasa kini iaitu kefahaman setiap orang secara umum tentang virus ini, epidemik dan juga maklum balas yang diperlukan. Ada kebiasaan baharu yang muncul dalam era ini seperti mencuci tangan, menggunakan pelitup muka, adanya kebijakan menggunakan pelitup muka lumayan efektif untuk mengurangi sebaran virus korona. Menurut Zinn (2021) pengalaman covid-19 ini telah memaksa kemungkinan para pekerja untuk bekerja dari rumah atau work from home sangat diperlukan dalam kondisi yang sudah tersedia jejaring internet kini. Perkembangan digital ini juga berpengaruh pada pertumbuhan di bidang pendidikan, banyak institusi pendidikan seperti sekolah mahupun universiti yang dapat mengajar dalam talian dan membina kapasiti untuk menjalankan pembelajaran talian. Perkembangan digital ini tidak hanya terletak pada bidang pekerjaan ataupun Pendidikan, tetapi juga pada capaian pada digital media yang melanjutkan kehidupan sosial di masa pandemik, di satu sisi media dapat memberikan maklumat, mengawal sokongan, dan melanjutkan hubungan sosial semasa di pandemik. Di satu sisi kondisi ini membuat segalanya lebih fleksibel, bernilai dan terencana.

Kondisi kenormalan baharu ini secara tidak langsung mempengaruhi perkembangan ekonomi di pelbagai negeri. Startup sebagai salah satu syarikat perniagaan tentu mengalami adaptasi. Startup di Yogyakarta selama pandemik ini menunjukkan adanya beberapa perkembangan, ada startup yang masih berjuang, ada beberapa startup yang gagal, tetapi juga justeru ada startup baharu yang tengah bermunculan pasca adanya wabak pandemik.

\subsubsection{Adaptasi Startup dalam Kenormalan baharu}

Hal-hal yang dirasakan para pelaku startup dalam menyikapi kenormalan baharu adalah adaptasi perpindahan daripada luar talian menuju dalam talian. Amadea memaparkan, cabaran yang tentu dihadapi adalah permasalahan luar talian, kerana suasana luar talian itu tidak dapat tergantikan dan jauh lebih menyenangkan. Budaya ini terjadi pada dalaman kumpulan startup yang berada di Yogyakarta, dengan perjumpaan langsung dan berinteraksi satu sama lain, saling bertukar ilmu, berbincang secara langsung. Namun di satu sisi yang lain, dalam talian inkubator Amadea dapat mengembangkan jangkauan lebih luas lagi, tidak hanya di Kawasan Provinsi Daerah Istimewa Yogyakarta sahaja, tetapi juga merangkul kepada startup yang berada di kawasan lain seperti Semarang, Surabaya dan kota lain.

Cahaya menyatakan terdapat adaptasi yang pada awal pertama kali lumayan sulit kerana belum terbiasa. Tetapi justeru kerana awal mula adanya pandemik itu membuat kumpulan syarikat semakin solid. Pirli menjelaskan bahawa dalam kondisi pandemik itu merupakan tugasan daripada startup untuk dapat berkembang dan beradaptasi dengan situasi yang tengah dihadapi. 
"Selepas ini kita akan hidup berdampingan dengan korona, saya rasa kedepannya situasi kalau agak membaik, secara pertumbuhan mungkin kita lebih cepat, tapi hambatannya kerana kita masih baru baby startup, kita masih belum kokoh, masih banyak yang perlu kita perbaiki". (Pirli)

Puspa juga merasakan hal itu, bahawa terdapat acara luar talian yang sangat berkurang, hal ini sangat berpengaruh kerana Puspa tergabung dalam komuniti startup game pada kawasan Yogyakarta yang secara budaya sering mengadakan perjumpaan. Pengalaman Puspa yang lain, sebetulnya ia berharap dapat pergi keluar negeri semasa pandemik. Startup milik Puspa berjaya lulus untuk membentangkan idea game mereka ke negeri Jerman, tetapi sayangnya kerana kebijakan pandemik membuat mereka tidak dapat pergi. Di sisi lain, Puspa juga menyukai bahawa ia lolos pelatihan inkubator selama 4 bulan di Bandung tetapi kerana pandemik, kuliah tetap dapat berjalan bersamaan dengan pelatihan.

Mufid menyedari bahawa hal paling berpengaruh daripada adanya pandemik adalah berkurangnya intensiti aktiviti luar talian. Startup miliK Mufid dibentuk pada tahun 2019, sebelum pandemik terjadi, banyak sekali aktiviti yang berjalan luar talian seperti menghadiri, mengisi, membentangkan idea dan seminar berisikan gizi kesihatan di tempat-tempat Coworking Space di Yogyakarta. Tetapi selama pandemik Mufid tidak boleh membuat peristiwa luar talian, sehingga lebih banyak webinar online tentang gizi di media. Menurut Matahari, sebagai sebuah inkubator sering mengadakan peristiwa luar talian seperti kumpulan, mengunjungi kampus lain, dan juga melaksanakan acara talkshow, kegiatan ini berlangsung rutin sebelum pandemik, tetapi semasa pandemik semua beralih dalam talian.
"Jadi kita lebih tertuntut untuk menggunakan teknologi dan memaksimalkan peran digital. Tapi kemudian kita tidak dapat berjumpa secara langsung, itu yang jadi poin paling kurang". (Matahari).

Secara budaya, menurut En. Rony hal yang paling terasa berbeza antara sebelum dan sesudah pandemik iaitu budaya perjumpaan, budaya jawa senang sekali untuk berjumpa dan mengadakan kumpulan yang bererti, kalau perjumpaan langsung dapat melihat sopan santun, ada saling bersalaman, dengan adanya pandemik dan kemajuan teknologi maklumat sekarang ini budaya itu menjadi tidak ada.

\subsubsection{Trend startup dalam Kenormalan baharu}

Dalam kajian ini, kebanyakan tanggapan daripada pelaku startup dalam menghadapi wabak pandemik iaitu masih menyimpan rasa optimisme untuk bangkit. Meskipun fenomena pandemik sempat menghambat pertumbuhan dan minat startup di Indonesia, tapi menurut beberapa informan dalam penyelidikan ini, perkembangan startup akan terus berkembang, tidak perduli dengan pelbagai ancaman pandemik.

Sebagai contoh menurut Cahaya arah aliran startup akan tetap meningkat. Menurut Cahaya, salah satu startup yang dapat berkembang iaitu startup yang bersifat pembangunan mapan. Cahaya optimistik bahawa startup akan membuka peluang kerja baharu bagi banyaknya belia di Indonesia, trend kerja di syarikat biasanya bergerak kaku tanpa inovasi, tetapi dengan munculnya skema startup, syarikat dapat bertumbuh penuh idea, fleksibel, kreatif, dan menjadi salah satu kunci bahawa ekosistem dapat 
berkembang. Cahaya menjelaskan bahawa terdapat label yang melekat bagi belia bahawa bekerja di sebuah startup merupakan suatu kebanggaan dan prestij.

"Akan ada ada seribu startup yang baharu, dengan adanya pandemik hal ini memengaruhi hawa pemuda untuk bergabung dengan startup". (Cahaya)

Menurut Mufid dan Igman seharusnya perkembangan startup dapat meningkat ke arah positif kerana banyak bermunculkan idea-idea perniagaan baharu dan juga dengan adanya pandemik ada sedikit paksaan berpindah ke arah digital, sehingga idea startup yang berbasis teknologi dan digital akan terus meningkat, teknologi semakin berkembang, maklumat semakin mudah didapati, hal ini membina belia Indonesia untuk lebih cepat belajar dan melihat peluang. Di satu sisi permasalahan juga semakin banyak dan menunggu untuk diselesaikan dengan idea-idea kreatif para pengasas startup.

"Belia di Indonesia itu lumayan ahli di bidang tech startup atau startup
teknologi, pasti akan ramai muncul startup bagus yang keren-keren. Hal
ini harus dengan sokongan pihak kerajaan dan pihak
inkubator/accelerator startup". (Igman)

Puspa menyatakan bahawa startup tentang permainan masih sangat menjanjikan, terlebih semasa pandemik. Ketika pandemik hadir, menurut Puspa, gamer bertambah banyak, berdasarkan data daripada pihak kerajaan ekonomi banyak ditingkatkan daripada penghasilan game daripada negara Indonesia. Hal ini berimpak kepada belia yang banyak terjun dalam industri startup permainan, kerana peluang yang sangat menjanjikan dan sokongan. Selaras dengan Rene yang menyatakan bahawa pemasaran di Indonesia itu sangat besar dan menjanjikan.

"Startup semakin meningkat, semakin ramai macamnya, di setiap lini kehidupan dapat dibina startup, pasti banyak idea yang muncul, kerana itu berarti setiap permasalahan dapat dijadikan idea tertentu, kalau di scale up jadi teknologi bakal okay, jadi menurut saya akan banyak". (Rene)

Berbeza dengan pendapat para pengasas dan aktor startup, Matahari selaku pihak universiti dan inkubator memiliki pandangan yang sedikit berbeza, iaitu, perkembangan startup lebih pegun berbanding tahun-tahun sebelumnya. Namun begitu, di satu sisi, perniagaan memiliki kekuatan baharu dengan teknologi digital yang semakin berperanan dan dinikmati oleh belia selaku aktor startup di Indonesia. Matahari melihat bahawa antusiasme aktor startup nampak berkurang, yang mana hal tersebut terlihat dalam konteks penyertaan kumpulan dalam aktiviti yang dianjurkan inkubator sebelum pandemik.

"Menurut saya kelihatan berkurang, kalau dulu saya bina acara petang hari, ada sharing session, kumpul-kumpul, ngopi-ngopi, kalau sekarang engangement kita jadi lebih kurang, kemudian tidak mudah bagi kami untuk melihat potensi mereka, maunya difasilitasi program yang seperti apa, itu jadi kita cukup kesulitan" (Matahari).

Selaras dengan Matahari, menurut Amadea daripada pihak inkubator melihat pada dalaman startup dalam konteks wabak pandemik banyak startup yang tidak dapat 
bertahan. Menurut Amadea, biasanya kerana tidak dapat menutup biaya syarikat, hal ini tidak terlepas dengan status pelaku startup di Yogyakarta yang kebanyakan merupakan seorang siswazah, biasanya startup bukan menjadi penghasilan utama para siswazah dan dilakukan secara part time. Tetapi meski begitu, Amadea yakin bahawa pasca pandemik, startup akan tetap meningkat. Amadea melihat bahawa apa yang dilakukan startup-startup ini semakin bererti. Nilai tambah daripada pandemik iaitu terkait sisi budaya kerja yang lebih fleksibel untuk menggabungkan antara online dan offline. Dan juga dilihat daripada sisi potensi startup itu sendiri, yang dapat lebih berfokus untuk membuat impak yang lebih besar dalam menghadapi persoalan pandemik.

"Jadi semakin banyak sesuai versi mereka sendiri dalam menjawab permasalahan. Startup masih akan berkembang di beberapa bidang, di beberapa sektor kerana semakin banyak permasalahannya, harapannya makin banyak startup yang dapat menajawab persoalan itu, kami bergerak menyediakan wadah untuk berkembangnya startup". (Amadea)

En. Rony optimis bahawa perkembangan startup tetap terus meningkat. Menurut En. Rony kehidupan ke depan akan selalu berkaitan dengan teknologi maklumat sehingga startup itu menjadi salah satu tumpuan atau salah satu sokongan yang cukup bererti dalam melaksanakan kegiatan masyarakat.

"Jadi semakin ramai orang menggunakan teknologi digital, otomatis
startup memiliki peluang yang besar, oleh sebab itu, kami menyiapkan
infrastruktur, asas kebijakan, modal manusia, basis data agar
masyarakat boleh hidup menikmati perkembangan teknologi, tidak
menjadi konsumen, tapi jadi pelaku, tidak hanya memanfaatkan
penggunaan, tapi juga pelaku startup". (En. Rony)

Secara keseluruhan, aktor dan penggiat startup, mengemukakan pendapat yang sama, iaitu, merasa optimis bahawa trend perkembangan startup akan terus meningkat, tanpa menghiraukan pandemik. Tentu ada pendapat yang menyatakan bahawa awal-awal pandemik banyak startup yang berguguran dan sempat lesu, tetapi para aktor startup tetap memegang rasa optimistik dan yakin bahawa trend startup akan semakin berkembang dalam menghadapi kenormalan baharu di masa depan.

Tidak dapat dinafikan bahwa pandemik Covid-19 telah memberikan impak ke atas sektor ekonomi, kehidupan masyarakat, dan konsep kerja dalam syarikat. Menurut Carroll dan Conboy (2020), dalam era ini sangat diperlukan inovasi dalam berniaga. Sebagai contoh, perlu ada perubahan ke atas model kerja yang lebih cepat secara atas talian, adaptasi ke atas norma sosial yang berubah, amalan dan normalisasi terhadap teknologi, sehingga akhirnya perancangan, penerapan, penggunaan teknologi harus disesuaikan sebagai sebuah norma baharu bagi perkembangan startup.

\section{Kesimpulan}

Secara keseluruhan, dapat dirumuskan bahawa semasa bermula pandemik covid-19 terdapat beberapa startup yang bankrap, startup yang bertahan dan juga startup yang baru tumbuh. Pandemik di satu sisi memberikan halangan dan cabaran bagi beberapa startup, tetapi di satu sisi lain memberikan kemudahan dan peluang baharu. Cabaran semasa pandemik yang dihadapi oleh startup adalah berbeza-beza, dan setiap startup berusaha untuk bertahan dengan pelbagai proses adaptasi. Impak negatif pada awal 
pandemik telah menyebabkan banyak startup yang sukar untuk beradaptasi, tetapi seiring berjalannya waktu muncul proses kerja baharu sehingga ada nilai-nilai positif daripada pandemik. Pelaksanaan lockdown semasa pandemik, melahirkan adaptasi baru seperti yang dinyatakan oleh Zinn (2021), iaitu, proses penyatuan atau keterkaitan antara manusia, alam dan teknologi dalam kalangan startup di Yogyakarta. Hal ini jelas dapat dilihat dengan meningkatnya urusan secara atas talian atau perkhidmatan berdasarkan talian. Dalam lain perkataan, teknologi maklumat memberikan peluang baharu ke atas perkembangan startup. Namun begitu, proses tersebut memerlukan adaptasi budaya sehingga dapat membentuk kenormalan baharu (kenormalan baharu) dalam startup beraktiviti.

\section{Penghargaan (Acknowledgement)}

Terima kasih kepada kesemua informan yang telah memberikan kerjasama dalam menjayakan kajian ini.

\section{Kewangan (Funding)}

Kajian dan penerbitan ini tidak menerima sebarang tajaan atau bantuan kewangan.

\section{Konflik Kepentingan (Conflict of Interests)}

Penulis tidak mempunyai konflik kepentingan dalam proses penyelidikan ini.

\section{Rujukan}

Aditif. (2021). Kajian Lanskap Industri Digital Kreatif D.I Yogyakarta Tahun 2021. Kantor Perwakilan Bank Indonesia D.I Yogyakarta dan Asosiasi Industri Digtial Kreatif (ADITIF). https://aditif.id/download/

Buheji, M., Ahmed, D., \& Jahrami, H. (2020). Living Uncertainty in the Kenormalan baharu. International Journal of Applied Psychology, 10(2), 21-31.

Carroll N., \& Conboy K. (2020). Normalising the "kenormalan baharu": Changing techdriven work practices under pandemic time pressure. International Journal of Information Management, 55(3), 1-6.

Creswell, J. (2007). Qualitative Inquiry \& Research Design Choosing Among Five Approaches. Sage Publications

Creswell, J. (2004). Research Design: Pendekatan Kualitatif, Kuantitatif, dan Mixed. Pustaka Pelajar.

Hamzah, A. (2010). Kaedah kualitatif dalam penyelidikan sosiobudaya. Jurnal Pengajian Media Malaysia, 6(1): 1-10

Karl, K. A., Peluchette, J. V., \& Aghakhani, N. (2021). Virtual work meetings during the COVID-19 pandemic: The good, bad, and ugly. Small Group Research, 1-23.

Katadata. (2020). Strategi Bertahan startup digital Di Tengah Pandemi COVID-19. Katadata

Center. https://katadata.co.id/katadatainsightscenter/analisisdata/5f1a622e0cc4 6/strategi-bertahan-startup-digital-di-tengah-pandemi-covid-19

Kuckertz, A., Brändle, L., Gaudig, A., Hinderer, S., Morales Reyes, C. A., Prochotta, A., Berger, E. S. C. (2020.) Startups in times of crisis - A rapid response to the COVID19 pandemic. Journal of Business Venturing Insights 13(1), 1-13. 
Muhyiddin. (2020). Covid-19, Kenormalan baharu, dan Perencanaan Pembangunan di Indonesia. Jurnal Perencanaan Pembangunan: The Indonesian Journal of Development Planning 4(2): 240-252.

Pramono, C. A., Manurung, A. H., Heriyati, P., \& Kosasih, W. 2021. Factors Affecting Startup Behavior and Start-up Performance During the COVID-19 Pandemic in Indonesia. Journal of Asian Finance, Economics and Business 8(4): 809-817.

Putri, R. N. 2020. Indonesia dalam Menghadapi Pandemi Covid-19. Jurnal Ilmiah Universitas Batanghari Jambi 20(2): 705-709.

Salamzadeh, A., \& Kesim, H. (2015). Startup Companies: Life Cycle \& Challenges. Proceedings of the 4th International Conference on Employment, Education and Entrepreneurship (EEE), Belgrade, Serbia.

Tiffany, A., Yuniar, A., Febrian, A., Austeen, J., Suryaputra, L., Hannah, M., Kevin, T., \& Bagas, W. (2020). Strategi Pemilik Bisnis Startup Di Indonesia Hadapi Pandemi Covid-19. Journal VICIDI, 10(2), 55-65.

Wahidah, I., Athallah, R., Hartono, N. F. S., Rafqie, M. C. A., \& Septiadi, M. A. 2020. Pandemik COVID-19: Analisis Perencanaan Pemerintah dan Masyarakat dalam Berbagai Upaya Pencegahan. Jurnal Manajemen Dan Organisasi 11(3): 179-188.

Zinn, J. O. (2021). Conclusions: Towards a sociology of pandemics and beyond. Current Sociology Monograph, 69(4), 603-617. 